\title{
Influence of information asymmetry on sustainability and changeability of region's economy
}

\author{
Elena Gushchina \\ Volgograd State Technical University \\ Faculty of Economics and management \\ Volgograd, Russia \\ 1055@mail.ru
}

\author{
Elena Vitalyeva \\ Volgograd State Technical University \\ Faculty of Economics and management \\ Volgograd, Russia \\ lenkooooo@gmail.com
}

\author{
Sergey Volkov \\ Volgograd State Technical University \\ Faculty of Economics and management \\ Volgograd, Russia \\ e-mail: ambiente2@rambler.ru
}

\begin{abstract}
A region is an open socio-economic system specified by its interaction with external environment. Regulating such complicated systems is associated with choosing the best management decision from a set of possible variants. Although there are new progressive approaches to revealing and solving the problems of administrating the territories of the Russian Federation by developing new strategies of socio-economic development, this procedure preserves some inertial symptoms caused by the problems of information support and exchange. The resulting information asymmetry increases transactional expenses, puts obstacles in the way of economic agents to the best decision and prevents them from allocating required resources, and contributes to the emergence of different types of risks. The article analyzes how the negative effects of information asymmetry influence both the stability and changeability of Russian territories' socio-economic development. Theoretical and methodological approaches to investigating the mechanism of response to and recovery from the asymmetry are proposed.
\end{abstract}

Keywords - information asymmetry, negative effects, stability, changeability, regional socio-economic development

\section{INTRODUCTION}

Regular socio-economic changes taking place in Russia have an effect on the characteristics of the processes of regional development. Capital, resources, and information serve as the objects which are utilized by territories for exchange with their external environment through its transparent boundaries. A regional system has constant and regulated interactions characterized by the variability of both its external and internal environments. The unstable economic situations in most of Russia's regions, the territorial disproportions, and the differential nature of the economic management of regional systems are the results of not only asynchronous development and resource endowment but also regional policies of low efficiency and negative effects provoked by information asymmetry.

This information issue arising at the level of the subjects of the Russian Federation imposes a negative effect on the structure of socio-economic relationships which takes into consideration both a regional identity and the peculiarities and trends relating to the performance of a single regional system, damages the competitive positions of a definite territory which are defined by its effective business economy creating an authentically attractive image, and lowers the stability of socio-economic development.

\section{MATERIALS AND METHODS (MODEL)}

The structural basis of improving the methods of regional management consists of sustainable development concepts as the basic paradigm of the 21 st century.

The Concept of Long-Term Socio-Economic Development of the Russian Federation until 2020 (Strategy 2020) can be attributed to the fundamental research papers that have predetermined the principles, forms and prospects of regional management under the current national policy. Strategy 2020 is believed to become the reference model for subsequent conceptual projects and solutions, and its focus is on steady regional socio-economic improvement which should be 
harmonized at the domestic level and which is aimed at achieving positive changes in the living standards of the population and at both reproducing and developing the social, economic, resource and ecological potential of the regions. Strategy 2020 gives grounds for the methods of developing regional systems by creating favorable conditions to unlock the development potential of each region undertaking the following steps: - to overcome infrastructural and institutional constraints; - to adjust the economies of the regions to socioeconomic changes; - to assist with the development of human potential; - to improve the coordination of the activities of the public and local authorities, businesses and social structures ${ }^{1)}$.

\section{RESULTS AND DISCUSSION}

Sustainable development is herein referred to as harmonious positive changes in the most important spheres of social, governmental or individual activity. By applying a set of goal-oriented and long-term socio-economic measures, these changes provide a country with the ability to resist the turbulence provoked by its unfavorable foreign-policy situation under the current geopolitical circumstances in the foreign and domestic markets.

The sustainable socio-economic development of a state is specified by the efficient activity of its economic entities, i.e., regions and big cities (Gushchina, E.G., 2015, pp. 23-28). Particular emphasis has recently been placed by domestic and foreign researchers upon creating a new and prospective system focused on the sustainable development of territories (Granberg, A.G., 2008, p. 495).

The stability of any open and complicated socio-economic system (including a region) coincides with its ability to adapt to the changes of its external environment for the purpose of carrying on its operation. It is impossible for this system to achieve absolute stability, which may have negative effects on its development; i.e., the ability to full adaptation is as hazardous as inadaptability (Frolov, D.P., 2013, p. 374).

The system cannot adapt unless it has been undergoing a change. Regional systems have an internal source of change, and these changes can involve different parts of the internal structure of such systems and can be either qualitative or quantitative, depending on specific shifts in the external environment (Avdiyskiy, V.I., Bezdenezhnykh, V.M., 2017) ${ }^{2}$. In this context, a system development process is specified by an intricate relationship between the phenomenon of stability and that of changeability. While stability is associated with the tendency to preserve and to improve a system with the prescribed functions, changeability serves as a necessary criterion for the further development of any socio-economic process. The stability of a territorial system is characterized by harmonized interrelations between its structural elements, on the one side, and by its ability to internal restructuring, on the other side, thus helping to prevent and to respond disturbances

\footnotetext{
1) Available at http://base.garant.ru/194365/ (accessed 03-082017).

2) Available at http://info.e-cm.ru/magazine/66/eau_66_85.htm (accessed 01-08-2017).
}

and thus contributing to the system's performance with an acceptable level of efficiency (Gushchina, E.G., 2015, p.25).

The requirements for the package treatment of the issues on regional system development, which are included in the duties of public and local authorities at the regional level, are practically spontaneous. The analysis of these processes has helped reveal that transformation changes are both organic and properly coordinated only in few Russian subjects.

In order to take effective management decisions for the purpose of enhancing the sustainability of territorial development, it is essential for each government authority to assess the current situation in its region and to define correlations among the internal condition, external interferences and the effects of spontaneous events (Morozova, I.A., et.al., 2016, pp. 30-36). To measure the influence of internal factors on a regional system, an investigation should be conducted on the region's naturalresources potential, demographic situation, human potential, existing settlement patterns, infrastructural circumstances, current economic conditions (industrial, corporate, clusterbased), current development trends, economic compatibility, ethno-cultural circumstances and inter-ethnic relations. The external factors that influence regional development are as follows: - macroeconomic situation in a country; - measures taken by its federal authorities; - economic and geographical position of a region in the corresponding okrug, country and on the global stage; - level of involvement in the system of global trade, information and financial exchange. Studying the aforementioned factors contributes to assessing their effect in general, revealing a region's resource potential, and defining better conditions for its further development in accordance with potential risks. Using the analysis findings, a specialpurpose scenario and top-priority goals are developed with regard to regional improvement (Yushkova, N.G., 2016, p.37).

Stable socio-economic development forecasts must be based primarily on conducting a scientific analysis of the current situation and on revealing key problems and real tendencies related to regional development in accordance with the existing internal and external information. Nevertheless, the array of socio-economic, demographic, legal and other relevant information required is constantly growing, but it is both hardly organized and inaccessible to not only citizens but also most of government officers, thus provoking a situation of information asymmetry.

Information asymmetry, incompleteness, unreliability or fraudulent misrepresentation don't meet the requirements of the target groups including government authorities, businesses, investors, local population, all acting as both objects and subjects of information asymmetry. This situation prevents each group from making better decisions and from reconciling their interests. Hence, the potential and prospects of regional development can be underestimated, and Russian entities' transformation processes can become intensive.

The problem is not that information asymmetry should be liquidated, but it is that what methods and tools should be applied to overcome the potential negative effects of the asymmetry. Concerning the Government's economic policy, neither the Federal Government nor any single federal ministry or department has a fair and true view of how the decisions taken by them are distributed across the regions. 
However, any of such decisions has a clear indication of what region it is bound to, and any of them should be put into force within a definite region even if the decision is industry- or object-oriented and doesn't directly deal with the issues of the region. Every decision (economic, investment, social, etc.) has indirect effects imposed on its region. And this circumstance is hardly considered by the Government's executive bodies when making policy decisions and putting them into force, thus reducing their efficiency and reasonableness (Malchinova, A.S., 2017).

All these circumstances prove the necessity to develop a generic mechanism which will possess all characteristics of structural integrity and which will be able to represent the full regional identity of a definite territory. To design the mechanism, it appears possible both to apply the existing schemes of strategic analysis for revealing and updating current problems and to implement those marketing approaches which stimulate a conscious use of the competitive advantages of a region, contribute to its competent positioning, and promote a territory actively and efficiently (Gushina, E.G., 2017, pp. 23-29). Moreover, it is obligatory to execute an effective integrated policy focused on triggering territorial improvement, retaining and gaining new resources for the region by using such economic mechanisms as fiscal policy, government protection, subventions, etc. By applying the policy, new competitive advantages will be gained, and stability characteristics in regard to socio-economic development will be qualitatively improved at a regional level on a long-term horizon (Gushina, E.G., et.al., 2016, pp. 6-8).

The most urgent issue relating to the functioning of Russia's government control system is associated with limited access to information - i.e., broader availability to government executive bodies and local authorities - and with lack of feedback from individuals and businesses, although a set of specific programs have been introduced and carried out. One of the first attempts taken by the government executive bodies to achieve information publicity was The Federal Program "Electronic Russia (2002-2010)" focused on a workflow management system and communication between the government structures and its citizens, enabled by means of government web-sites. The Russian e-government concept approved afterwards was to raise the quality of both information exchange and the services provided by the state. The Program "Information Society (2011-2020)" was developed in 2010. The program is aimed at improving the quality of life by using information and communication technologies. Then, several regulations including the RF Government Regulation and Decree that obliged the government authorities to publish information on the Internet were introduced3). Nevertheless, all these concepts, programs and regulations didn't promote better regulatory effectiveness. The performance of a body of executive power was monitored inside the body, which didn't provide adequate control over the existing situation.

To structure basic problems relating to information provision for the greater coherent functioning of the government executive authorities of the Russian Federation and its subjects, the following aspects can be highlighted:
Insufficiency, delays and asymmetry of information exchange prevents concerted and consistent decision-making, thus creating a zone of conflicts at the federal and regional administrative levels;

Information coming from the federal authorities to the regions bears the form of either decisions already taken or regulatory documents, vs. information coming from the regions to the federal bodies is given in a formalized manner and calls for the implementation of these decisions;

Regular information exchange between the levels of public authorities is not regulated (excluding statistical reports), and the procedure of information exchange is specified by the current conjuncture and subjective circumstances;

Necessity to provide information for the purpose of better cooperation among the federal and regional executive authorities isn't properly represented by the documents regulating the procedure of joint administration for the RF's Central District and its subjects (Malchinova, A.S., 2017).

Timely solutions to the problems of information provision, a proper procedure for documenting information updates, openness of government executive authorities will contribute to smaller information asymmetry and greater regulatory effectiveness at the regional and municipal administrative levels. Introducing tax-and-expenditure, property, investment or marketing passports of the RF's subjects and municipal entities will help clearly assess the ability of each territory to its development by using the internal resources and will provide proper inter-budgetary communication based solely on objective criteria, thus avoiding subjectivism and conflict situations while allocating the state's profit (Malchinova, A.S., 2017).

\section{CONCLUSION}

Thus, information provision for sustainable development is preconditioned by the presence of true and consistent information of high quality including the following formats: statistical reports and analytical data describing the aftereffects of the decisions already taken and completed or those being implemented; - short- and long-term forecasts; completed plans and those being under implementation or under development; - stabilization and development programs; - socio-economic development sustainability indicators. Effective management decisions aimed at raising the sustainability of a territory's socio-economic development appear possible on conditions, as follows: - all information on a region's economy should be collected and analyzed; existing negative effects resulted from information asymmetry should be assessed; - new information providing smaller asymmetry should be produced and distributed; - public opinion and responses should be monitored; - obtained results should be controlled.

\section{Acknowledgment}

Funded by the RFBR, Project \# 17-32-00006

3) Available at http://cyberleninka.ru (accessed 08-08-2017). 


\section{References}

[1] Avdiyskiy, V.I., Bezdenezhnykh, V.M., 2017. Uncertainty, variability and inconsistency in analyzing the risks of economic system behavior. Effective anticrisis management, 2017. http://info.e-cm.ru/magazine/66/eau_66_85.htm.

[2] Granberg, A.G., 2008. Basics of regional economy. M.: GU VSHE. 2008. 495 p.

[3] Gushchina, E.G., 2015. Concept of the structural model of sustainable regional development. In Economics: Theory and Practices, 2015, iss.3, pp. 23-28.

[4] Gushina, E.G., et.al., 2016. Mechanism of responding to negative effects of information asymmetry as an instrument for increasing the sustainability of Russian territories' socio-economic development under macroeconomic and geopolitical instability. Competitive power of economics in the era of globalization: Russian and international experience. In Proceedings of the $5^{\text {th }}$ International Scientific Conference Dedicated to the $140^{\text {th }}$ Anniversary of the NIU "BelGU" (Belgorod, 2409-2016), 2016, pp. 6-8.

[5] Gushina, E.G., 2017. Theoretical and methodological approaches to studying the mechanism of responding to negative effects of information asymmetry as an instrument for increasing the sustainability of Russian territories' socio-economic development. In Sustainable
Development of Science and Education, 2017, iss.7, pp. 23-29.

[6] The Concept of Long-Term Socio-Economic Development of the Russian Federation 2020 (approved by the Government of the Russian Federation on 17-11-2008, \# 1662-p). http://base.garant.ru/194365/.

[7] Morozova, I.A., et.al., 2016. Quality of management decisions and sustainable development of business structures. In VolGTU Bulletin: Urgent Issues on Russian Economic Reforming (Theory, Practices, Prospects), Volgograd, 2016, vol.1, iss.180, pp. 30-36.

[8] Regional view on Russia's government economic policy ed. by Malchinova, A.S., 2017. Centre for Problem Analysis and Public Management Projects. M: Nauchniy Ekspert, 2007. 113 p.

[9] Regulating information openness of executive authorities. [08-08-2017] http://cyberleninka.ru.

[10] Sergeeva, O.E., 2011. Portfolio structure of assessing and choosing perspective regional businesses. In Regional Economy: Theory and Practices, 2011, vol.3, iss.186, pp.23-29.

[11] Frolov, D.P., 2013. Marketing paradigm of regional development: monograph. Volgograd: VolGU, 2013. 157 p.

[12] Yushkova, N.G., 2016. Strategy and tactics of regional change management: current experience, problems and assessment peculiarities. Moscow: Izadatelskiy Dom "Economicheskaya Gazeta", 2016. 200 p. 